\title{
Responses of Different Morphological Attribute of Rosa hybrida L. cv. Kardinal to Saline Water Irrigation
}

\author{
Afif Ur Rehman ${ }^{1, *}$, Atif Riaz ${ }^{1}$, Muhammad Iqbal ${ }^{1}$, Jamil Shafi', Waqas Ahmad ${ }^{1}$ \\ ${ }^{1}$ Institute of Horticultural Sciences, University of Agriculture, Faisalabad (38040) Pakistan \\ ${ }^{2}$ Department of Plant Pathology, University of Agriculture Faisalabad (38040) Pakistan \\ *Corresponding Author:uaf3840@gmail.com
}

Copyright (C) 2014 Horizon Research Publishing All rights reserved.

\begin{abstract}
Salinity remained as a serious threat to agricultural land in all over the world. Salt stress conditions affect all aspects of plant growth and development. When we raised plant in different levels of $\mathrm{NaCl}$, it caused the change not only in morphological characteristics, but also had adverse effect on physiological characteristics of the plant. Among seven levels of salinity, $\mathrm{T}_{0}$ showed better result against other treatments. $\mathrm{T}_{0}$ (canal water) proved the best treatment for all the understudy characters such as plant height decreased significantly with the increase in salinity level. Plant height, number of leaves plant ${ }^{-1}$, number of branches plant ${ }^{-1}$, leaf area, number of flower plant $^{-1}$, flower diameter, flower quality, fresh weight of flower, dry weight of a flower presented superior results in canal water rather than $2.5 \mathrm{dS} / \mathrm{m}, 5 \mathrm{dS} / \mathrm{m}, 7.5 \mathrm{dS} / \mathrm{m}, 10 \mathrm{dS} / \mathrm{m}, 12.5 \mathrm{dS} / \mathrm{m}$ and 15 $\mathrm{dS} / \mathrm{m}$ salinity levels.
\end{abstract}

Keywords Rosa hybrid, Salinity, $\mathrm{NaCl}$, Kardinal, Canal water,

\section{Introduction}

Soil salinity is a condition characterized by high concentration of soluble salts. Soils are classified as saline when the electrical conductivity (EC) is $4 \mathrm{dS} \mathrm{m}^{-1}$ or more [1]. Among various a biotic stresses, salinity is the major factor that reduces/harms the plant growth and development, decreases germination and ultimately decreases plant establishment and yield. The salinity is a major problem for all the countries in the world. The total global area of salt-affected soils has been recorded to be about 830 million hectares [2]. Salinity affects 19.5 percent of irrigated land and 2.1 percent of dry land agriculture in the world [3]. Most of the saline soil has arisen from natural causes, by the accumulation of salt for a long period of time in arid to semi-arid regions of the world [4]. Plants get different necessary nutrients which are available to the plants in soluble form and the plant enlargement is decreased by unnecessary addition of these soluble salts [5].
Agricultural productivity is severely affected by soil salinity and the damaging effect of salt accumulation in agricultural soils has become an important environmental concern [6]. Higher concentration of soluble salts in soil causes reduction and delay in germination of seeds of many species, it is observed that salts may affect germination rate to a greater extent than the germination percentage [7]. Seeds with high germination percentage under salt stress may be expected to achieve high germination percentage and rapid seedling establishment and hence ultimate high yield [8]. Most of the ornamental plants are glycophytes and vary as salt-suscepsptible to fairly salt-resistant. Salinity has deleterious effect on plant growth, nutritional balance, flowering marketable quality of plant, including visual injury, flower distortion and reduced stem length [9]. Salinity stops growth and, in high concentration, changes plant morphological characteristics and their anatomy and has lethal affect on plant organism [10]. Growth, yield and quality decrease may occur due to a decrease in the ability of plants to take up water from the soil solution and the destruction of soil structure caused by salinity [11].

Now a day's different farming techniques have been introduced to overcome the problems of saline areas or the area which is under other stresses conditions [12]. Salt resistant plants give better result because they have the ability to uptake more water in such condition under saline soil while in most cases salinity retards the plant growth because of saline soils requires resources as there is a limited availability of quality water and low soil permeability 13]. Singh, [14] claimed that Rosa damascene can be successfully grown on salt affected soil having $\mathrm{pH}$ of 7.8 to 8.8 due to high salt uptake. Skiminia, [15] described that salt tolerance in ornamental to four levels of salinity having ECe of 140, 300, 600 and $1200\left(10^{-5}\right)$ mhos and reported that Aurocaria heterophylla, Asparagus densiflorus and Hibiscus rosasinencsia considered the salt tolerance plants. Keeping in view the potential of plant salt tolerance in the literature, the present study was conducted aims to assess the effect of salinity on different morphological features of Rosa hybrida L.cv. Kardinal and to checks the response of the plants under salt stress conditions and its tolerance level. 


\section{Materials and Methods}

Experiment was conducted in pots at Floriculture Research Area, University of Agriculture, Faisalabad during year (2012-13) in order to investigate the effects of salinity on growth and flowering quality of Rosa hybrida L.cv. Kardinal. The experiment was laid out in the Randomized Complete Block Design (RCBD) with seven different treatments of salinity ranging from $2.5 \mathrm{dS} / \mathrm{m}$ to $15 \mathrm{dS} / \mathrm{m}$ salinity each with three replications. Seedlings of month were transplanted in the pots $(20 \mathrm{~cm}$ diameter and $22 \mathrm{~cm}$ depth) containing a mixture of silt and leaf manure in the ratio of $1: 1$ as a growth medium. These seedlings were allowed to establish for 20 days before the start of applying different salinity levels $(2.5,5.0,7.5,10.0,12.5,15.0 \mathrm{dS} / \mathrm{m}$ of $\mathrm{NaCl}$ salt of solution). The experiment was comprised of weighing the soil that was $1500 \mathrm{gm}$ (growth medium) in each pot and the salinity levels were developed artificially by adding the solution of $2.5,5.0,7.5,10.0,12.5,15.0 \mathrm{dS} / \mathrm{m}$ of $\mathrm{NaCl}$ salt solution along with control. Data for different morphological attributes was collected as:

Plant height $(\mathrm{cm})$ and number of leaves plant ${ }^{-1}$ as by Wood and Roper [16] With the help of leaf area meter leaf Area $\left(\mathrm{cm}^{2}\right)$ calculated by formula as

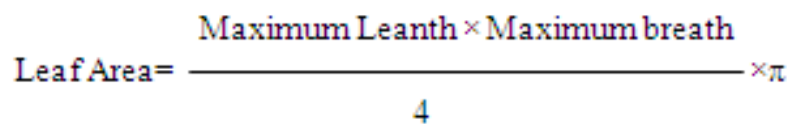

Number of branches plant- $^{1}$ was counted per plant and then average was worked out. Number of flowers plant- ${ }^{1}$ was counted regularly during blooming period of the crop and then average was worked out, for size of flower $(\mathrm{cm})$ diameter of all flowers was measured with the help of vernier caliper and their average was taken out. For fresh weight of a flower (g) one flower from each plant was collected randomly and then weighed for its fresh weight in grams on electric balance and their average was worked out and for dry weight of a flower $(\mathrm{g})$ flowers were dried in oven at $65^{\circ} \mathrm{C}$ for 48 hours and then weight on electric balance. In this way, dry weight of flowers was recorded. Fresh and dry weight ratio of flower was calculated by dividing the fresh weight over dry weight of a flower and average ratio was computed. Flower quality evaluation was done by adopting the method described by Cooper and spokas [17] and Dest and Guillard [18].

\subsection{Statistical Analysis}

Standard procedure was followed to record the data. Data collected was analyzed by performing analysis of variance (ANOVA) and treatment means were compared according to Duncan's Multiple Range Test at $5 \%$ level of probability [19].

\section{Results}

\subsection{Effect of NaCl Salinity on Plant Height (cm)}

Plant height data revealed highly significant results for different levels of $\mathrm{NaCl}$ (Table 2). Comparison of means revealed significant superiority of $\mathrm{T}_{0}$ (canal water) over rest of the treatments by producing $51.43 \mathrm{~cm}$ height and $\mathrm{T}_{1}(2.5$ $\mathrm{dS} / \mathrm{m}$ ) secured the second position by producing plant height $(51.17 \mathrm{~cm}) . \mathrm{T}_{3}(5 \mathrm{dS} / \mathrm{m})$ and $\mathrm{T}_{4}(7.5 \mathrm{dS} / \mathrm{m})$ were statistically similar. Minimum plant height was obtained at $\mathrm{T}_{6}(15 \mathrm{dS} / \mathrm{m})$. $\mathrm{T}_{3}(5 \mathrm{dS} / \mathrm{m})$ and $\mathrm{T}_{4}(7.5 \mathrm{dS} / \mathrm{m})$ were statistically similar. Minimum plant height was obtained at $\mathrm{T}_{6}(15 \mathrm{dS} / \mathrm{m})$ (Table 1). The results presented in table (Table 3 ) exhibited that plant height is positively correlated with flower quality, number of leaves, number of branches, number of flowers, fresh weight, dry weight, diameter of flower and leaf area, whereas negatively associated with fresh and dry weight ratio of the flower.

\subsection{Effect of $\mathrm{NaCl}$ salinity on Number of Leaves Plant ${ }^{-1}$}

Statistical analysis for these indices has reflected highly significant results in relation to NaCI levels (Table 2). Mean values for number of leaves exhibited that $\mathrm{T}_{0}$ (canal water) produced more number of leaves (39.44) plant $^{-1}$. $\mathrm{T}_{1}(2.5$ $\mathrm{dS} / \mathrm{m}$ and $\mathrm{T}_{2}(5 \mathrm{dS} / \mathrm{m})$ secured second and third position by producing 37.63 and 30.45 number of leaves plant ${ }^{-1} . \mathrm{T}_{3}(7.5$ $\mathrm{dS} / \mathrm{m})$ produced 27.21 leaves which was followed by $\mathrm{T}_{4}(10$ $\mathrm{dS} / \mathrm{m})$ and $\mathrm{T}_{5}(12.5 \mathrm{dS} / \mathrm{m})$ by producing 18.11 and 14.55 leaves, respectively. $\mathrm{T}_{6}(15 \mathrm{dS} / \mathrm{m})$ produced minimum number of leaves (9.63) (Table 1). Number of leaves plant ${ }^{-1}$ are positively correlated with number of branches, number of flowers, fresh weight, dry weight of a flower, flower diameter and leaf area. While it was negatively correlated with fresh and dry weight ratio of flowers, (Table 3 ).

\subsection{Effect of $\mathrm{NaCl}$ Salinity on Number of Branches Plant $^{-1}$}

Data regarding number of branches plant ${ }^{-1}$ is presented in (Table 2) as analysis of variance after having it been subjected to statistical analysis indicated highly significant results. It is obvious from mean table (Table 1 ) that $\mathrm{T}_{0}$ (canal water) produced maximum number of branches (6.05). $\mathrm{T}_{1}$ $(2.5 \mathrm{dS} / \mathrm{m})$ and $\mathrm{T}_{2}(5 \mathrm{dS} / \mathrm{m})$ behaved significantly alike from statistical point of view with average number of branches 5.96 and 5.85, respectively. $\mathrm{T}_{6}(15 \mathrm{dS} / \mathrm{m})$ produced only 3.29 branches plant ${ }^{-1}$. This represents highly adverse effects of salinity on the number of branches. Number of branches plant $^{-1}$ are positively correlated with number of leaves, number of flowers, fresh weight, dry weight, flower diameter and leaf area while negatively correlated with fresh and dry weight ratio flowers (Table 3).

\subsection{Effect of $\mathrm{NaCl}$ Salinity on Leaf Area $\left(\mathrm{cm}^{2}\right)$}

leaf area was processed for statistical analysis and is presented in (Table 2) as analysis of variance and statically 
analysis reflected highly significant results for $\mathrm{NaCl}$ levels. $\mathrm{T}_{0}$ (canal water) secured superiority over all other treatments with average leaf area of $18.53 \mathrm{~cm}^{2} . \mathrm{T}_{1}(2.5 \mathrm{dS} / \mathrm{m})$ obtained $16.98 \mathrm{~cm}^{2}$ leaf area followed by $T_{2}$ with leaf area of 15.81 $\mathrm{cm}^{2} . \mathrm{T}_{3}(7.5 \mathrm{dS} / \mathrm{m})$ and $\mathrm{T}_{4}(10 \mathrm{dS} / \mathrm{m})$ were statistically at par whereas $\mathrm{T}_{5}(12.5 \mathrm{dS} / \mathrm{m})$ and $\mathrm{T}_{6}(15 \mathrm{dS} / \mathrm{m})$ were statistically similar with each other.

\subsection{Effect of NaCl Salinity on Number of Flowers Piant ${ }^{-1}$}

Number of flowers plant ${ }^{-1}$ data indicated highly significant results for $\mathrm{NaCl}$ levels (Table 2). Values of treatment means (Table 2) exhibited that $\mathrm{T}_{0}$ (canal water) produced maximum number of flowers $(4.46) . \mathrm{T}_{1}(2.5 \mathrm{dS} / \mathrm{m})$ and $\mathrm{T}_{2}(\mathrm{dS} / \mathrm{m})$ secured second and third position by producing 4.25 and 4.00 flowers respectively. Minimum numbers of flowers were produced by $\mathrm{T}_{6}(15 \mathrm{dS} / \mathrm{m})$ and it was statistically at equivalence with $T_{5}(12 \mathrm{dS} / \mathrm{m})$. Number of flowers plant ${ }^{-1}$ is positively correlated with, fresh weight, dry weight, flower diameter and leaf area. While number of flowers plant ${ }^{-1}$ has negative association with ratio of fresh and dry weight of flowers (Table 3).

\subsection{Flower Diameter}

Flower diameter was processed for analysis of variance and results obtained revealed highly significant difference among different salinity levels (Table 2). Comparison of means (Table 1) exhibited that $\mathrm{T}_{0}$ (canal water) excelled rest of treatments by producing large sized flowers as compared to all other treatments. Data revealed that $\mathrm{T}_{0}$ (canal water) produced maximum diameter $(2.1 \mathrm{~cm})$ of a flower followed by $T_{1}(2.5 \mathrm{dS} / \mathrm{m})$ which was statistically different from rest of the treatments. $\mathrm{T}_{6}(15 \mathrm{dS} / \mathrm{m})$ produced minimum flower diameter $(1.8 \mathrm{~cm})$ followed by $\mathrm{T}_{5}(12.5 \mathrm{dS} / \mathrm{m})$ with flower diameter of $(1.9 \mathrm{~cm}) . \mathrm{T}_{4}(10 \mathrm{dS} / \mathrm{m})$ was statistically at par with $\mathrm{T}_{3}(7.5 \mathrm{dS} / \mathrm{m})$. Flower diameter had positive correlation with leaf area (Table 3).

\subsection{Effect of NaCl Salinity on Flower Quality:}

Flower quality processed for analysis of variance highly significant for $\mathrm{NaCl}$ salinity levels (Table 2 ). Mean values for flower quality indicated (Table 2) that $\mathrm{T}_{0}$ (canal water) produced better quality flowers with a rating of (8.26). $\mathrm{T}_{1}$ $(2.5 \mathrm{dS} / \mathrm{m})$ and $\mathrm{T}_{2}(5 \mathrm{dS} / \mathrm{m})$ secured second and third position with flower quality of 8.01 and 7.59 , respectively. $\mathrm{T}_{3}(7.5$ $\mathrm{dS} / \mathrm{m})$ and $\mathrm{T}_{4}(10 \mathrm{dS} / \mathrm{m})$ were statistically at par with flower quality of 7.28 and 7.15 , respectively. $T_{6}(15 \mathrm{dS} / \mathrm{m})$ produced poor quality (5.29) flowers followed by 6.06 which was produced by $\mathrm{T}_{5}(12.55 \mathrm{dS} / \mathrm{m})$. Flower quality is positively correlated with number of leaves while flower quality has negative association fresh and dry weight ratio of flowers (Table 3).

\subsection{Effect of NaCl Salinity on Fresh Weight of A Flower} (g)

Fresh weight of a flower were presented as analysis showed highly significant results for $\mathrm{NaCl}$ levels (Table 2). In order to make a comparison of various $\mathrm{NaCl}$ levels, their values were arranged in descending order (Table 2). Mean values for fresh weight of a flower revealed that $T_{0}$ (canal water) produced maximum fresh weight $(6.95 \mathrm{~g})$ followed by $\mathrm{T}_{1}\left(2.5 \mathrm{dS} / \mathrm{m}\right.$ with fresh weight of $6.85 \mathrm{~g}$. $\mathrm{T}_{2}(5 \mathrm{dS} / \mathrm{m})$ and $\mathrm{T}_{3}$ $(7.5 \mathrm{dS} / \mathrm{m})$ produced $6.73 \mathrm{~g}$ and $6.48 \mathrm{~g}$ fresh weight respectively. $\mathrm{T}_{5}(12 \mathrm{dS} / \mathrm{m})$ was significantly different from $\mathrm{T}_{4}(10 \mathrm{dS} / \mathrm{m})$. Minimum fresh weight $(6.15 \mathrm{~g})$ was produced by $\mathrm{T}_{6}(15 \mathrm{dS} / \mathrm{m})$. Fresh weight of a flower is positively correlated with dry weight, flower diameter and leaf area while it is negatively correlated with ratio of fresh and dry weight of flowers (Table 3).

\subsection{Effect of $\mathrm{NaCl}$ salinity on dry weight of flower (g)}

Dry weight of a flower (g) was processed for statistical analysis exhibited highly significant results for $\mathrm{NaCl}$ levels (Table 2). In mean table (Table 1), dry weight (1.43 g) was recorded in $\mathrm{T}_{0}$ (canal water) which was statistically similar to dry weight $(1.40 \mathrm{~g})$ of $\mathrm{T}_{1}(2.5 \mathrm{dS} / \mathrm{m})$. Similarly $\mathrm{T}_{3}(7.5 \mathrm{dS} / \mathrm{m})$ and $\mathrm{T}_{2}(5 \mathrm{dS} / \mathrm{m}$ were statistically at par with each other by producing dry weight of $1.27 \mathrm{~g}$ and $1.25 \mathrm{~g}$, respectively, Minimum dry weight $(1.10 \mathrm{~g})$ was observed by $\mathrm{T}_{4}(15 \mathrm{dS} / \mathrm{m})$ followed by $\mathrm{T}_{5}(12.5 \mathrm{dS} / \mathrm{m})$. Dry weight of a flower is positively correlated with flower diameter and leaf area. While it is negatively correlated with ratio of fresh and dry weight of flowers (Table 3).

\subsection{Fresh and Dry Weight Ratio}

Fresh and dry weight ratio of flower is presented in depicted highly significant results for $\mathrm{NaCl}$ levels (Table 2). Treatments means (Table 1) revealed that $\mathrm{T}_{0}$ (canal water) secured top position regarding fresh and dry weight ratio (5.60g). $\mathrm{T}_{1}(2.5 \mathrm{dS} / \mathrm{m})$ and $\mathrm{T}_{2}(5 \mathrm{dS} / \mathrm{m})$ obtained second and third positions with $5.43 \mathrm{~g}$ and $5.22 \mathrm{~g}$ ratio, respectively. $\mathrm{T}_{3}$ $(7.5 \mathrm{dS} / \mathrm{m})$ and $\mathrm{T}_{4}(10 \mathrm{dS} / \mathrm{m})$ were statically similar. The minimum fresh and dry weigh ratio (4.86) was observed by $\mathrm{T}_{6}(15 \mathrm{dS} / \mathrm{m})$ which was at par with $4.87 \mathrm{~g}$ ratio of $\mathrm{T}_{5}(12.5$ $\mathrm{dS} / \mathrm{m})$. Ratio of fresh and dry weight of flowers is negatively correlated with flower diameter and leaf area (Table 3). 
Table 1. Variation in morphological attributes of Rosa hybrida L.cv. Kardinal under different salinity levels

\begin{tabular}{|c|c|c|c|c|c|c|c|c|c|c|}
\hline Treatments & $\begin{array}{l}\text { Plant height } \\
\quad \text { (cm) }\end{array}$ & $\begin{array}{l}\text { Number of } \\
\text { leaves plant }^{-1}\end{array}$ & $\begin{array}{l}\text { Number of } \\
\text { branches } \\
\text { plant }^{-1}\end{array}$ & $\begin{array}{c}\text { Leaf area } \\
\left(\mathrm{cm}^{2}\right)\end{array}$ & $\begin{array}{c}\text { Number of } \\
\text { flowers pIant }{ }^{-1}\end{array}$ & $\begin{array}{c}\text { Flower } \\
\text { diameter }(\mathbf{c m})\end{array}$ & Flower quality & $\begin{array}{l}\text { Fresh weight } \\
\text { of a flower (g) }\end{array}$ & $\begin{array}{l}\text { Dry weight of } \\
\text { flower (g) }\end{array}$ & $\begin{array}{c}\text { Fresh and dry } \\
\text { weight ratio }\end{array}$ \\
\hline $\mathrm{T}_{0}$ & 51.43 & 39.44 & 6.05 & 18.53 & 4.46 & 2.1 & 8.26 & 6.95 & 1.43 & 5.60 \\
\hline $\mathrm{T}_{1}$ & 51.17 & 37.63 & 5.96 & 16.98 & 4.25 & 2.1 & 8.01 & 6.85 & 1.40 & 5.43 \\
\hline $\mathrm{T}_{2}$ & 49.80 & 30.45 & 5.85 & 15.81 & 4.00 & 2.0 & 7.59 & 6.73 & 1.27 & 5.22 \\
\hline $\mathrm{T}_{3}$ & 48.81 & 27.21 & 5.58 & 13.48 & 3.66 & 2.0 & 7.28 & 6.48 & 1.25 & 5.12 \\
\hline $\mathrm{T}_{4}$ & 46.80 & 18.11 & 5.15 & 12.51 & 3.22 & 1.9 & 7.15 & 6.33 & 1.21 & 4.99 \\
\hline $\mathrm{T}_{5}$ & 44.47 & 14.55 & 3.54 & 10.99 & 2.96 & 1.9 & 6.06 & 6.24 & 1.15 & 4.87 \\
\hline $\mathrm{T}_{6}$ & 42.80 & 9.63 & 3.29 & 10.14 & 2.74 & 1.8 & 5.29 & 6.15 & 1.10 & 4.86 \\
\hline
\end{tabular}

Table 2. Mean squares of absolute values for morphological attributes of Rosa hybrida L.cv. Kardinal under different salinity levels

\begin{tabular}{|c|c|c|c|c|c|c|c|c|c|c|c|}
\hline SOS & df & $\begin{array}{l}\text { Plant height } \\
\quad \text { (cm) }\end{array}$ & $\begin{array}{l}\text { Number of } \\
\text { leaves plant }^{-1}\end{array}$ & $\begin{array}{c}\text { Number of } \\
\text { branches plant }^{-1}\end{array}$ & $\begin{array}{l}\text { Leaf area } \\
\quad\left(\mathrm{cm}^{2}\right)\end{array}$ & $\begin{array}{c}\text { Number of } \\
\text { flowers } \\
\text { pIant }^{-1}\end{array}$ & $\begin{array}{l}\text { Flower diameter } \\
\quad(\mathrm{cm})\end{array}$ & $\begin{array}{l}\text { Flower } \\
\text { quality }\end{array}$ & $\begin{array}{l}\text { Fresh weight of } \\
\text { a flower (g) }\end{array}$ & $\begin{array}{l}\text { Dry weight of } \\
\text { flower (g) }\end{array}$ & $\begin{array}{c}\text { Fresh and } \\
\text { dry weight } \\
\text { ratio }\end{array}$ \\
\hline Varieties & 2 & 17.606 & 0.768 & 0.034 & 13.463 & 0.332 & 0.007 & 0.112 & 0.149 & 0.017 & 0.228 \\
\hline Replicate & 6 & 32.882 & 397.858 & 4.032 & 29.585 & 1.312 & 0.041 & 3.414 & 0.296 & 0.046 & 0.236 \\
\hline Error & 12 & 4.413 & 0.369 & 0.063 & 0.342 & 0.032 & 0.002 & 0.017 & 0.002 & 0.003 & 0.007 \\
\hline
\end{tabular}

Table 3. Correlation between different morphological characters of Rosa hybrida. L. cv. Kardinal as influenced by various salinity levels

\begin{tabular}{|c|c|c|c|c|c|c|c|c|c|}
\hline Characters & Plant Height & Flower Quality & $\begin{array}{c}\text { Number of } \\
\text { leaves/ plant }\end{array}$ & $\begin{array}{c}\text { Number of } \\
\text { branches/ plant }\end{array}$ & $\begin{array}{c}\text { Number of } \\
\text { flowers/ plant }\end{array}$ & Fresh weight & Dry weight & $\begin{array}{c}\text { Fresh/ Dry } \\
\text { weight Ratio }\end{array}$ & Flower diameter \\
\hline Flower Quality & $0.759^{* *}$ & & & & & & & & \\
\hline $\begin{array}{c}\text { Number of leaves/ } \\
\text { plant }\end{array}$ & $0.828 * *$ & $0.933 * *$ & & & & & & & \\
\hline $\begin{array}{l}\text { Number of branches/ } \\
\text { plant }\end{array}$ & $0.796^{* *}$ & $0.941 * *$ & $0.904 * *$ & & & & & & \\
\hline $\begin{array}{c}\text { Number of flowers/ } \\
\text { plant }\end{array}$ & $0.856^{* *}$ & $0.859^{* *}$ & $0.932 * *$ & $0.871^{* *}$ & & & & & \\
\hline Fresh weight & $0.611^{*}$ & $0.878^{* *}$ & $0.902 * *$ & $0.784 * *$ & $0.797 * *$ & & & & \\
\hline Dry weight & $0.620^{*}$ & $0.835^{* *}$ & $0.870^{* *}$ & $0.760^{* *}$ & $0.732^{* *}$ & $0.875^{* *}$ & & & \\
\hline $\begin{array}{c}\text { Fresh/ Dry weight } \\
\text { Ratio }\end{array}$ & $-0.549 *$ & $-0.882 * *$ & $-0.833 * *$ & $-0.786 * *$ & $-0.710^{* *}$ & $-0.927 * *$ & $-0.86^{* *}$ & & \\
\hline Flower diameter & $0.780^{* *}$ & $0.912 * *$ & $0.909^{* *}$ & $0.852^{* *}$ & $0.927^{* *}$ & $0.841 * *$ & $0.756^{* *}$ & $-725 * *$ & \\
\hline Leaf Area & $0.610^{* *}$ & $0.892 * *$ & $0.901 * *$ & $0.796^{* *}$ & 0.817 ** & $0.984 * *$ & $0.890^{* *}$ & $-926 * *$ & $0.852^{* *}$ \\
\hline
\end{tabular}

**Highly Significant at 5\% level of significance

*Significant at $5 \%$ level of significance) 


\section{Discussion}

For plant height, saline irrigation water function as a natural alternate to growth retardants (used by many grower to reduce plant height) and high concentration of salinity badly affects plant height. Similar findings were also reported by Patil and Wahmare [20] for the plant height in which they observed that plant growth at four salinity levels and all indices significantly declined with rising salinity levels. The occurrence of high concentrations of chlorine in the leaves eventually leads to leaf injury. Reduction in growth of plants under salt stress can be attributed to necrosis of the leaves which reduces the photo synthetically active area. These results are in accordance with findings of Cornish et al [21] who argued that by increasing $\mathrm{NaCI}$ irrigated water in chrysanthemum, numbers of leaves are reduced. It has been suggested that a restriction of $\mathrm{Na}$ transport from roots to shoots takes place, to shoots takes place, minimizing $\mathrm{Na}$ accumulation in leaves. Plants might protect themselves from sodium toxicity by minimizing the transport to the shoots. These observations were compared with Nolan et al. [22] and Mostafa et at. [23] who argued that salinity application decreased number of branches in Datura innoxia. Salinity causes loss of cell turgor and reduces leaf expansion rates. This, in turn, leads to reduction in the leaf area available for photosynthesis and a loss of productivity. Similar results were obtained by Ergazieva and Rakhimbaev [24] and Jesche and Stelter [25] who observed significant decrease in leaf area with increase in salinity level in irrigation water for lilac. Results for number of flowers were in accordance with Hughes and Hanan [26], Ishida et at. [27] and Speck and Sconncveld [28]. Similar reports have been described by Sonneveld arid Voogt [30] who attributed that gerberas, anthurium and chrysanthemum flower production decreased with increasing salinity levels. Any factor that interferes with nitrogen assimilation could cause a reduction in rose flowers production. One of these factors may be salinity which has shown to decrease the number of flowers. It indicated that diameter of a flower decreases with increasing salinity levels. These results are in line with the findings of Jesche and Stelter [25] who reported that increasing salinity levels result a negative effect on flower size in rose. Salinity effects also (depend on the type and concentration of salt used and on the plant species being tested. However, the presence of salts in irrigation water decreases flower quality and therefore leads to a lower economic benefit from the crop. So, it can be concluded that optimum level of salinity is very important in order to get best flower quality of Rosa, as indicated by Safi and Sawwan [31]. Rose plant growth is influenced by several factors such as light, temperature, relative humidity etc., but when environmental conditions are optimal, salinity appears to be one of the limiting factors for flower production. These results are in accordance with the findings of Speck and Sonneveld [28] who argued significant decrease in fresh weight of flowers by increasing salinity levels in Anthurium andreanum. Observations for dry weight were supported by the findings of Devit and Morris [29] who observed decline in dry weight with increasing salinity levels for Petunia hybrida. The decrease of total flower weight of rose was affected relatively by a decrease in the number of flowers and also related to decrease of the weight per flower. These results arc in link with findings of Ishida et al . [27].

\section{REFERENCES}

[1] United States Department of Agriculture. Organic Floriculture and Bedding Crops, Food Crops Grown Under Protection, Mushrooms, Nursery Crops, and Propagative Materials Grown on Certified and Exempt Organic Farms, 2008.

[2] J. Martinez-Beltran, C.L. Manzur. Overview of the salinity problem in the world and FAO strategies to address the problem, Proceedings of the international society forum, California, 2005.

[3] Anonymous. Indian Agriculture in Brief. 27th edition, Agriculture Statistics Division, Directorate of Economics and Statistics, Ministry of Agriculture, Govt. of India, 2000.

[4] P. Rengasamy. Transient salinity and subsoil constraints to dry land farming in Australian sodic soils: an overview, Australian Journal of Experimental Agriculture, Vol.42, 351-361, 2002.

[5] D. B. Alan, Salt Tolerance and Growth Potential of Horticultural and Landscape Plants, Turkish journal of Botany, Vol.18, 988-992, 1994.

[6] C. A. Jaleel, R. Gopi, P. Manivannan, R. Panneerselvam. Antioxidative potentials as a protective mechanism in Catharanthus roseus (L.) G. Don. Plants under salinity stress, Turkish Journal of Botany, Vol.31, 245-251, 2007.

[7] P. Lovato, J.P. Guillemin, S. Gianinazzi. Application of commercial arbuscular endomycorrhizal fungal inoculants to the establishment of micropropagated grapevine rootstocks and pineapple plants, Agronomy, Vol.12, 873-880, 1992

[8] M. E. Rogers, C.L. Noble, G.M. Halloran, M.E. Nicholas. The effect of $\mathrm{NaCl}$ on germination and early seedling growth of white clover (Trifolium repens L.) population selected for high and low salinity tolerance, Seed Science and Technology, Vol.23, 277-287, 1995.

[9] H. Greenway, R. Munns. Mechanism of salt tolerance in nonhalophytes. Plant Physiology, Vol.31, 149-190, 1980.

[10] T. Kozlowski, Responses of woody plants to flooding and salinity-Tree physiology monograph, Indian journal of Forestery, Vol.3, 13-15, 1997.

[11] E. G. Barrett-Lennard, The interaction between water logging and salinity in higher plants: Causes, consequences and implications. Plant soil, Vol.253, 35-54, 2003.

[12] R. H. Qureshi, E.G. Barrett-Lennard. Saline agriculture for irrigated land in Pakistan. A Hand Book. Australian centre for International, Australia, 1998.

[13] M. Ashraf, N. Yasmin. Responses of some arid zone grasses to brackish water. Tropenl and wirt, Vol.98, 3-12, 1997. 
[14] L. B. Singh, Utilization of saline-alkali soils for agro-industry without prior reclamation, Economy of Bottany, Vol.24, 175-179, 1970.

[15] C. A. Skiminia, Salt tolerance of ornamentals. Combined Proc.Internet. plant propagators Society, Vol.30, 113-118, 1980.

[16] Wood, Roper. Factors influencing activities of living as measuring plant growth Rhodes College. (n.d.) Botany:available online from http://www.rhodes.edu/biology/stinemetz/FPlants.htm

[17] R. J. Cooper, L.A. Spokas. Growth, Quality and foliar iron concentration Kentucky bluegrass treated with chelated iron sources, Journal of American Society of Horticultural Sciences, Vol.116, 798-801, 1991.

[18] W. M. Dest, K. Guillard. Nitrogen and Phosphorus nutritional influence on bentgrass Annual bluegrass community composition. Journal of American Society of Horticultural Sciences, Vol.112, 769-773, 1987.

[19] R. G. D. Steel, J.H. Torrie, D.A. Dicky. Principles and procedures of statistics, A Biometrical Approach. 3rd Ed. McGraw Hill, Inc. Book Co. U.S.A, 1997.

[20] V. K. Patil, V.K, P.R. Waghamare. Studies o growth curves on different characters of sapota in relation to various levels of soil ESP, Indian Journal of Horticulture, Vol.41, 200-205, 1984.

[21] K. Cornish, A.I. King, M.S. Reid, J.L. Paul. Role of ABA in stress induced water loss from potted chrysanthemum plants, Acta Horticulturae, Vol.167, 381-386, 1985.

[22] S. L. Nolan, T.H. Ashe, R.S. Lindstorm, D.C. Martens. Effect of sodium chloride levels on four four foliage plants grown at two light levels. Horticultural Sciences, Vol.17, 815- 817, 1982.
[23] M. B. Mostafa, A.R.E. Awad, M.H. Owais, A.A.K. Dawan. Physiological studies on growth, chemical composition and alkaline of Datura innoxia. Effect of salinity, Annuals of Agricultural Sciences Moshtohor, Vol.21, 937-949, 1984.

[24] R. I. Ergazieva, I.R. Rakhimbev. Effect of salinity on the growth of lilac seedlings, Byullenten' Glavnogo Botanocheskogo Sada., Plant Soil,11, 46-49, 1978.

[25] W. D. Jesche, W. Stelter. Ionic relations of garden orache, Atriplex hortensis L. growth and ion distribution at moderate salinity and function of bladder hair. Journal of Experimental Botany, Vol.34, 795-810, 1983.

[26] H. E. Hughes, J.J. Hanan. Effect of salinity in water supplies on greenhouse rose production, Journal of American Society of Horticultural Sciences, Vol.103, 694-699, 1978.

[27] A. Ishida, M. Mausi, A. Naukaya, T. Ogura. Salt tolerance of carnation in sand and soil cultures, Journal of Japanese Society for Horticultural Sciences, Vol.48, 322-326, 1979.

[28] B. Speck, C. Sonneveld. Effect of Nacl on growth and mineral composition of Acacia saligna insand culture, Journal of American Society of Horticultural Sciences, Vol.103, 441-446, 1985.

[29] D. A. Devitt, R.L. Morris. Morphological response of flowering annuals to salinity. Journal of American Society of Horticultural Sciences, Vol.112, 951-955, 1987.

[30] C. Sonneveld, W. voogt. Studies on salt tolerance of some flower crops grown under glass. Plant and soil, Vol.74, 41-52, 1983.

[31] Safi, m.I and J.S.Sawwan. Growth and flower quality of tree Rosa hybrida cultivars in response to rootstock.Mu'tah lil-Buhuth wad-Dirasat, Science Asia., Vol.19, 335-339, 1983. 